\title{
NEUROPSYCHOLOGICAL DETERMINANTS OF DYSLEXIA IN SCHOOLCHILDREN
}

\author{
Olena Kiparenko \\ Postgraduate Student of Chair for Differential and Special Psychology, \\ I. I. Mechnikov National University of Odesa, Ukraine \\ e-mail: elena.kiparenko@gmail.com, orcid.org/0000-0001-8577-0108
}

\section{Summary}

The article describes the results of the research exploring the link between the neurodynamic component of schoolchildren's psychic activity at the age of 7-12 and the level of mastering the reading skill at school. In the process of the research, we have detected the core neuropsychological criteria correlating with the level of reading technique and text understanding in schoolchildren. The neuropsychological research was made using A.R. Luria's battery of tests, by G.M. Glosman's method, adapted to childhood. We also used A.N. Kornyev and O.A. Ishymova's method of dyslexia diagnostics; texts for the research have been translated into Ukrainian.

We have pointed out two age groups of children andanalyzed how neurodynamic deficiency and audio-verbal and visual memory level influence the formation of dyslexia determinants in both of them.

In addition, we have addressed the link between child's development under the age of 1 , parents' complaints at the actual time and the level of a child's reading technique.

Keywords: dyslexia, neuropsychologicaldiagnostics, schooling skills, younger schoolchildren, neurodynamic factor, schoolingdifficulties.

\section{DOI: https://doi.org/10.23856/4631}

\section{Introduction}

The most common problem of schooling unsuccess and underperformance at the Ukrainian language is poor vocabulary, a great number of mistakes in writing, slow reading and failure to understand the text being read. So the problems of dyslexia makes schooling difficult for very many schoolchildren.

To make an incisive analysis of the reading malfunction, it is necessary to realize the extent and complexity of the reading skill's structure in the norm along with the individual peculiarities of mastering the reading skill in schoolchildren.

The study relevance, described in the article, is based on the fact that such notion as neuropsychology just starts to develop in Ukraine, while many countries have successfully used neuropsychological methods for the correction of schooling difficulties, in particular.

There is no general statistics on the quantity of children having difficulties in mastering the reading skill in Ukraine. According to the research made it was detected that about $10 \%$ of schoolchildren aged 7-12 have similar problems.

The problem of dyslexia in schoolchildren is studied by teachers, speech therapists, neuropsychologists, neurologists and neurophysiologists. It occurred quite long ago, but only last 10-20 years it has been given proper attention.

National scientists believe that up to $15 \%$ of younger schoolchildren experience problems with mastering the reading skill (Blinova, 2010; Pichugina, 2001). Statistical data provided by 
foreign sources differ a lot; the figures fluctuate from 5 to $35 \%$ of children with such problem. The specialists' opinions are controversial and ambiguous; it is also clear that there are no common terms in relation to the reading skill malfunction in schoolchildren and common methodology to overcome it.

The article presents the first part of the research; it describes the link between the difficulties of the first year of a child's life, insufficient maturity of some neuropsychological factors and actual development of the reading skill at the moment of examination.

We used A.R. Luria's battery of neuropsychological tests, adapted to childhood, and A.N. Kornyev and O.A. Ishymova's method of dyslexia diagnostics, translated into Ukrainian.

\section{The main part}

Neuropsychological approach to the difficulties in reading. From the neuropsychological perspective reading is a complex process, which implies several analyzers - first of all, visual, audial, motion and verbal ones.

In dyslexia one can observe general developmental problems of a child along with insufficient interhemispheric interaction, visual-spatial representations and low neurodynamic regulation.

Precisely due to A.R. Luria's concept and neuropsychological approach to child's development, we see that reading is a complex functional system, made up of many structural components, which is dynamically developing in the process of ontogeny and is performed by collaborative and integrated activity of different brain areas. It is important to note that underdevelopment of each brain area can result in different specific forms of dyslexia.

Using neuropsychological methods of research we can define typical links between the difficulty in reading and malfunctions in other psychic functions. Then there should be an appropriate and right-timed correction of these malfunctions, which will help to avoid forming of persistent dyslexia.

The impact of regulatory functions on the productive activity is manifested, first of all, in difficulty to be able to concentrate and to distribute attention. According to other studies, a child not always can distribute attention between the reading technique and the understanding of the text.

In one and the same symptom there can be different mechanisms from the perspective of neuropsychological analysis. For instance, if a child skips or shuffles vowels and consonants while reading, there can be both gnostic and regulatory difficulties.

Most of mistakes appear when a child is reading aloud. Neuropsychological analysis allows to define the components of psychical functions, which influence the mechanisms of dyslexia, and to differentiate it from neuroophtalmological pathology such as eyes movement disfunction or binocular vision.

Theoretical ground for the research. The research described in this article is based on the method by A.N. Kornyev (Kornyev, 1997). According to A.N. Kornyev, children with dyslexia, who were reading fast, made a lot of mistakes while reading aloud, but they had good understanding of what they were reading. In the other case children, who were reading slowly, made few mistakes, but they had poor understanding of the contents. While performing diagnosis, it is important to establish the link between the text type and the affirmations of the child reading it.

There is also such symptom of dyslexia as "guessing in reading". With this symptom a child subjectively adds meaning while reading; his semantic stereotypes get activated, then the forecasting by meaning gets disrupted, and the control of the perceptional unity fails. 
Thus we realize that the meaning forecasting while "guessing in reading" will be performed either on the level of a word's part or on the level of the whole word. There will be no traces of semantic and grammar links with syntagma. Here we can see such mechanisms as regulatory difficulties and holistic reading strategy malfunction.

Kornyev assumes that it can be explained by the predominance of mainly analytical-synthetic learning methods; they include the recognition of sound-letter matchings, merging into syllables and only after that the audial image of the whole word appears, prevailing over the global reading method, which implies the word image formation. Then in analytical-synthetic learning method the word gets related to an object or a picture, and only after this the transition to letter reading and letters merger takes place (Kornyev, 1997).

The described above proves that a child has a maximum quantity of characters, which he simultaneously recognizes while reading. This quantity forms a notion of "operational reading unit". In its turn, this operational reading unit is a minimal quantity of characters, which is preserved in the process of receiving and processing information. The improvement of the reading skills implies specifically the process of increasing and automating the operational reading units.

Besides, in the process of reading a child is forming a rhythmical word structure. First a child learns the words easiest for reading (choreic and iambic structure), then more complex ones (amphibrach, dactyl and anapaest). At this point a child starts recognizing the difference between the isolated phoneme sounding and various ways of pronouncing it. Wrong stresses will evidence for the underdevelopment of the mother tongue's rhythmic structure, in particular, which is also common for children with dyslexia.

The contents of the research. The standardized method of reading skill analysis (SMRSA) and Operational reading units test (ORUT) were created by the Russian authors A.N. Kornyev and O.A. Ishymova to diagnose the malfunctions of reading skills in children. The approbation of the questionnaire was made on several groups of schoolchildren from Moscow and St.Petersburg, attending 2-6 forms. In 2020 we started creating the Ukrainian versions of the tests.

We considered it helpful to translate the name of the tests into Ukrainian, as our versions of the tests measured an ability to read Ukrainian.

The aim of the tests is the study of the globalizing potential of a professional, but the Ukrainian version of the questionnaire is planned to be modified so that it would be directed to the study of reading skills in the setting of a New Ukrainian School (NUS) program implementation. This is what constituted the aim of the research. Based on the aim of the research, the following tasks were set:

1. Elaboration of the tasks samples (translation, creating stimulus material). Creating a pilot version, trying to keep the contents and understanding in the texts of the stimulus material and considering social-cultural norms;

2. Descriptive analysis of the tests' results (SMRSA and ORUT);

3. Standardization of partial results and defining their common values.

4. Definition of constructive validity of the integral tests' results (SMRSA and ORUT);

5. Criterion validity of the integral results by correlating the received parameters with relevant criteria.

The research involved 61 children from Kiev and Odessa. The sampling was divided by age ( 7 years old -3 children, 8 years old -11 children, 9 years old -17 children, 10 years old 16 children, 11 years old -9 children, 12 years old -5 children).

Based on the sampling, there were two groups formed, nearly equal in size: 7-9 years old $(\mathrm{n}=31)$ and $10-12$ years old $(\mathrm{n}=30)$. Further analysis was made mostly in these two groups separately. 
The age groups are equivalent in all social-demographic parameters except the residence. Thus, the children examined in Kiev were older than the children examined in Odessa.

\section{Results and discussion}

We have established a significant correlation between the marker NW1 (number of words per 1 minute of SMRSA test) and the grade by Apgar score. This correlation could be observed among children in the group of 10-12 years old and was marked by the positive sign. It should be noted that in the group of children of 7-9 years old the correlation was also positive, but didn't show statistical significance.

The absence of such trend in children of the given age can be explained both by a small sampling size and by the certain developmental peculiarities of a child's higher mental functions. We assumed that these malfunctions, which appeared in the process of prenatal development, manifest mostly at that particular age, when the pressure on a child is growing $(r=0,439 ; p=0,015)$.

Such questionnaire data as separate words and short phrases showed statistically significant correlations with the marker NW1 in the group of children aged 10-12 (separate words $r=-0,492 ; p=0,006$, short phrases $r=-0,444 ; p=0,014$ ).

Correlation coefficients were negative, which proved that the more delay a child

hadin speech development, the worse he/she passed the first test SMRSA. To our

opinion, this can be related to the developmental delay of neuropsychological

factors, which are important for reading - simultaneous synthesis and visual

motoriccoordination.

It should be noted that although in the group of children aged 7-9 such correlations were marked with the negative sign, they were not statistically significant (separate words $\mathrm{r}=-0,301$; $\mathrm{p}=0,100$, short phrases $\mathrm{r}=-0,115 ; \mathrm{p}=0,539$ ).

The stress should be also made on such criterion in the questionnaire as the delay of speech development, which also didn't show any statistically significant correlation in any of the two groups. We believe it is related to the fact that the latter criterion is more general, and the previous ones were more concrete subjective evaluations of children's early development made by their parents.

The marker NW1 also determined additional correlations with the marker of academic progress, and in the group of children aged 7-9 this correlation was statistically significant $(\mathrm{r}=0,430 ; \mathrm{p}=0,016)$.

The link between the reading speed and successful study at the primary school is evident and has been explored in scientific works (L. Vygotsky, E. Symernitskaya, M. Bezrukih). It shows that NW1 marker is characterized by high concurrent validity being compared to such external criteria as academic progress and can be also used in the further research to forecast the success in study in future, which is the question of prognostic validity research.

Thereafter we present the analysis and relation of the brain's first functional unit to the reading process in children.

Firstly, we evaluated validity of the given method to the markers describing the work of the brain's first functional unit. The research has been conducted on the basis of the Luria's three functional unit model of the brain (1973).

Structures of the first block of the brain include divisions of medulla, mesodiencephalic, hypothalamus-diencephalic and limbic areas, along with mediobasal divisions of the frontal and temporal lobes, which is the cortex of the activation processes (Luria, 1973). These structures provide optimized balance between activation and inhibitory processes in the nervous system. 
Among parents' complaints about their children's peculiarities in schooling, the statistically significant correlations with NW1 marker determined the complaints about deliberation $(r=-0,357 ; p=0,049$ in the group of children aged 7-9 and $r=-0,191 ; p=0,313$ in the group of children aged 10-12). Correlation coefficients were characterized by the negative sign and this trend was statistically significant in the group of children aged 7-9. According to research made by T.V. Akhytina, E.Y. Mayveyeva and A.A. Romanova (Akhytina et al., 2012), activity regulation disfunctions, including deliberation, are to some extent common for all children under test having difficulties in study, and are conditioned by the malfunction of subcortical area, specifically the first functional unit of the brain.

Such indices as immediate and deferred audio-verbal memory showed additional correlations with NW1. These correlations were characterized by statistical significance in the group of children aged 7-9 for immediate audio-verbal memory and in the group of children aged 10-12 - for deferred audio-verbal memory. A.V. Semenovich describes the variant of neurodynamic deficiency as subcortex disfunction. The main symptoms in this case are unstable criteria of activity efficiency (difficulties in entering the task, productivity fluctuation, quick exhaustion, deliberation). Here we can see the memory selectiveness disruption regardless the modality along with a relatively sufficient volume and substantiality of traces.

Visual memory index also determined additional correlation coefficients with NW1 marker, and in the group of children aged 7-9 this coefficient was statistically significant $(\mathrm{r}=0,417 ; \mathrm{p}=0,020)$.

As for memory defects, their presence negatively correlated with MW1 marker in both groups. Nevertheless, in the group of children aged 7-9 these correlation coefficients were statistically significant (perceptivesubstitutions $r=-, 499 ; \mathrm{p}=0,004$ ).

While studying attention, we rated the overall grade, which characterized the success in filling Schulte tables and time in seconds for each of the five tables. Comparing the results in the age groups, it should be mentioned that in the group of children aged 10-12 there were no statistically significant correlations detected. At the same time, in the group of children aged 7-9 the additional correlation coefficient between NW1 marker and overall grade of attention study was detected, and there were negative statistically significant correlations with the time of completion of the third $(r=-0,490 ; p=0,005)$, the fourth $(r=-0,505 ; p=0,004)$ and the fifth trial $(\mathrm{r}=-0,457 ; \mathrm{p}=0,010)$. The received data represent the dynamics of the reading skill consolidation with age, lowered reliance of a child's reading technique on the level of attention focus in older age, as the reading skill gets automatized.

Analyzing attention defects, it was stated, that such criteria as insufficiency of attention selectiveness $(\mathrm{r}=-0,413 ; \mathrm{p}=0,021)$, distraction from task completion $(\mathrm{r}=-0,472 ; \mathrm{p}=0,007)$, overall retardation and aspontaneity $(r=-0,660 ; p=0,000)$ form statistically significant correlations with NW1 marker. The sign of the correlation coefficients is negative and specifically the younger age group shows the detected trends.

While analyzing speech defects, significant correlation between NW1 marker and micro/ macrography in writing was detected $(\mathrm{r}=-0,563 ; \mathrm{p}=0,001)$. Thecorrelationcoefficientwhich characterized this link was negative. This proves that with the increase of such defects the speed of test completion (SMRSA) decreased, which could be explained by child's possible exhaustion.

\section{Conclusions}

Thus, there is no common diagnostic method and approach to the difficulties in mastering the reading skill in Ukraine at the moment. We realize that the problem of dyslexia in children 
is the reason for the further difficulties in mastering other school subjects - the Ukrainian language and literature, maths (especially solving problems), history, geography and others.

The research has shown the persistent correlation between a child's development under 1 year, the formation of some neuropsychological factors and the extent of mastering the reading skill at the moment of examination.

In the foreground, while examining the structures of the first functional brain unit we can observe the statistically significant value of attention deficiency while filling Schulte's table in three last trials in children aged 7-9 and correlation of this value with the reading technique criteria (number of words per 1 minute). In the background of low neurodynamics we can trace the correlation between modal-unspecific memory form and the NW1 marker.

The results allow us to work further in this direction and to create a model of relation between the level of neuropsychological factors formation for two age groups of children and the extent of mastering the reading skill from two perspectives - reading technique and understanding of what is being read.

Such model will be very helpful in creating an individual intervention program for a child with dyslexia.

\section{References}

Ahutina T.V., Polonskaya N.N., Pylaeva N.M., Maksimenko M.Yu. (2012). Nejropsihologicheskoe obsledovanie. Nejropsihologicheskaya diagnostika, obsledovanie pisma i chteniya mladshih shkolnikov [Neuropsychological examination. Neuropsychological diagnostics, examination of writing and reading of younger students]. Moskow: Sfera. [in Russian].

Bezrukih M.M., Machinskaya R.I., Farber D.A. (2009). Strukturno-funkcionalnaya organizaciya razvivayushegosya mozga $i$ formirovanie poznavatelnoj deyatelnosti $v$ ontogeneze rebenka [Structural and functional organization of the developing brain and the formation of cognitive activity in the ontogenesis of a child]. Moskow: Fiziologiya cheloveka. [in Russian]. Emelyanova E.N. (2010). Sluchaj korrekcii shkolnoj neuspevaemosti po prichine nizkoj nejrodinamiki protekaniya psihicheskih processov [A case of school failure correction due to low neurodynamics of the course of physical processes]. Moskow: Eksmo. [in Russian].

Glozman Zh.M. (2010) Nejropsihologicheskoe obsledovanie: kachestvennaya I kolichestvennaya ocenka dannyh. [Neuropsychological examination: qualitative and quantitative assessment of the data]. Moskow.: Smysl [in Russian].

Kornev A. N.(1997). Narushenyya chtenyya i pysma u detey: uchebno-metodycheskoe posobye. [Violation of reading and writing in children: teaching aid]. St. Petersburg: YD MyM, [in Russian].

Lalaeva R.Y.(2004) Narushenyya rechy y ykh korrektsyya u detey s zaderzhkoy psykhycheskoho razvytyya: uchebnoe posobye dlya studentov vysshykh uchebnykh zavedenyy. [Speech disorders and their correction in children with mental retardation: a textbook for students of higher educational institutions]. Moskow: VLADOS. [in Russian].

Luriya A.R. (2009) Osnovnye problemy nejrolingvistiki. [The main problems of neurolinguistics]. Moskow:Knizhnyj dom «LIBROKOM». [in Russian].

Luriya A.R. (2019). Vysshie korkovye funkcii cheloveka i ih narusheniya pri lokalnyh porazheniyah mozga. [Higher cortical functions of a person]. St. Petersburg: Piter [in Russian]. Vygotskij L.S. (1982) Psihologiya i uchenie o lokalizaciyah psihicheskih funkcij. [Psychology and the doctrine of the localization of mental functions]. Moskow: Pedagogika. [in Russian]. 